\title{
ANGELINA GRIMKÉ
}

\author{
Letter to Jane Smith
}

New Rowley, Mass., July 25, 1837

Angelina's increasing radicalism on the question of civil government accompanied her growing militancy on women's rights.

\section{MY DEAR JANE:}

I am truly glad thou wilt have an opportunity of becoming acquainted with brother Wright. He will tell thee all about his views of civil government \& be not afraid to be converted. I can truly say that until I embraced them I never understood the full extent of that Liberty wherewith Christ makes his followers free. It is indeed delightful to realize that $\mathrm{He}$ is our King, our lawgiver \& our judge. Without these views I know not how I could press forward in the path of difficulty which lies before me....

Some of these places are only villages, so that the few hundred who have come out have been a good many for the size of them. But our womanhood - it is as great offense to some as our Abolitionism. I will let $\mathrm{H} \mathrm{C} \mathrm{W}$ [Henry Clarke Wright] tell thee what a war is waged against it. The whole land seems roused to discussion on the province of woman, \& I am glad of it. We are willing to bear the brunt of the storm, if we can only be the means of making a breach in the wall of public opinion, which lies right in the way of woman's true dignity, honor \& usefulness. Sister Sarah does preach up woman's rights most nobly \& fearlessly, \& we find that many of our New England sisters are ready to receive these strange doctrines, feeling as they do, that our whole sex needs an emancipation from the thraldom of public opinion. What doest thou think of some of them walking $2,4,6 \& 8$ miles to attend our meetings?

But I must forbear - as Sisters voice failed her on account of cold. I have had to bear the brunt of the meeting for two days, speaking an hour \& a half today \& an hour and three quarters yesterday \& as it is $1 / 2$ past 9 I must say Fare thee well to night my dear friend.

Weld-Grimké Papers. 